\section{Effect of Gamma Radiation and Endodontic Treatment on Mechanical Properties of Human and Bovine Root Dentin}

Veridiana Resende Novais ${ }^{1}$, Priscilla Barbosa Ferreira Soares ${ }^{2}$, Carlla Martins Guimarães ${ }^{1}$, Laís Rani Sales Oliveira Schliebe ${ }^{1}$, Stella Sueli Lourenço Braga ${ }^{1}$, Carlos José Soares ${ }^{1}$

\begin{abstract}
This study evaluated the effect of gamma radiation and endodontic treatment on the microhardness and flexural strength of human and bovine root dentin. Forty singlerooted human teeth and forty bovine incisor teeth were collected, cleaned and stored in distilled water at $4{ }^{\circ} \mathrm{C}$. The human and bovine teeth were divided into 4 groups $(n=10)$ resulting from the combination of two study factors: first, regarding the endodontic treatment in 2 levels: with or without endodontic treatment; and second, radiotherapy in two levels: with or without radiotherapy by $60 \mathrm{~Gy}$ of Co- 60 gamma radiation fractioned into 2 Gy daily doses five days per week. Each tooth was longitudinally sectioned in two parts; one-half was used for the three-point bending test and the other for the Knoop hardness test (KHN). Data were analyzed by 3 -way ANOVA and Tukey HSD test $(\alpha=0.05)$. No significant difference was found for flexural strength values. The human dentin had significantly higher KHN than the bovine. The endodontic treatment and radiotherapy resulted in significantly lower KHN irrespective of tooth origin. The results indicated that the radiotherapy had deleterious effects on the microhardness of human and bovine dentin and this effect is increased by the interaction with endodontic therapy. The endodontic treatment adds additional negative effect on the mechanical properties of radiated tooth dentin; the restorative protocols should be designed taking into account this effect.
\end{abstract}

'Department of Operative Dentistry and Dental Materials, Biomechanics Research Group, Dental School, UFU - Universidade Federal de Uberlândia, Uberlândia, MG, Brazil ${ }^{2}$ Department of Periodontology and Implantology, Biomechanics Research Group, Department of Operative Dentistry and Dental Materials, Dental School, UFU - Universidade Federal de Uberlândia, Uberlândia, MG, Brazil

Correspondence: Carlos José Soares, Av. Pará, $n^{\circ} 1720$, Bloco 4L, Anexo A, Sala 42, Campus Umuarama, 38400-902 Uberlândia, MG, Brasil. Tel: +55-34-3225-8106. e-mail: carlosjsoares@ufu.br

Key Words: radiotherapy, endodontic treatment, human dentin, bovine dentin, Knoop hardness, flexural strength

\section{Introduction}

The improvements in quality of life of patients with head and neck tumors are increased with therapeutic interventions such as head and neck surgery and radiotherapy. However, ionizing radiation generally causes damage to healthy tissues adjacent to the radiation sites (1). Radiotherapy can modify substantially the mechanical strength of human enamel and dentin, producing more deleterious effects on the protein components than on the mineralized portion of dentin (2-5). Severe damage resultant from gamma radiation on the organic components of dentin, like collagen matrix, odontoblastic processes and pulp complex, should be considered in patients under head and neck oncologic treatment (6). These effects on dental substrate, mainly in dentin, may contribute to increased risk of radiation tooth decay associated with salivary changes, microbiota shift and high soft- and carbohydrate-rich foods (2).

Preserved pulp vitality impacts positively on the longevity of the restored tooth, however the high incidence of caries, dental traumas and iatrogenic interventions can lead to degenerative processes of the pulp (7). Changes in mechanical properties of dentin caused by to the action of irrigants, medication and root canal filling materials may predispose to tooth fracture (7). Additionally, the loss of structural integrity may increase the fracture occurrence (9).

Patients treated with head and neck tumors under radiotherapy may present some oral disturbances. The most evident complication for the dentition is the radiationinduced caries $(1,2)$. In the past, severely decayed teeth were frequently extracted prior to radiotherapy, but more recently, the teeth are submitted to root canal treatment to prevent tooth extraction (10). The modifications of the mechanical properties of dentin caused by radiotherapy are confirmed by several studies $(2,11,12)$. However, the additional effect caused by the endodontic therapy performed in radiated teeth remains unknown. Patients with filled root teeth requiring radiotherapy may have more alterations in the mechanical properties of the root dentin substrate.

Most of the in vitro tests of dental substrate are performed on extracted human teeth, which appear to be the perfect samples for such studies (13). The use of human teeth became difficult day by day, mainly caused by ethical restrictions, difficulty to obtain enough and adequate quality teeth; and also because it is difficult to control the source and age, with doubtful homogeneity of 
the substrate (13). The use of the bovine teeth as a substitute substrate for in vitro experiments that analyze the effect of the radiotherapy on dentin remains also unclear.

Therefore, the aim of this study was to evaluate the influence of gamma radiation and the endodontic treatment on Knoop hardness and flexural strength of human and bovine root dentin. The null hypotheses were: 1 , the radiotherapy associated with the endodontic treatment have no influence on the mechanical properties of root dentin; 2, the dentin type, human or bovine, hasno effect on the mechanical properties whether submitted or not to radiation and endodontic treatment.

\section{Materials and Methods}

Forty sound single-rooted human teeth and 40 bovine incisor teeth with similar age were selected (approved by the Committee for Ethics in Research, UFU \#538/07), cleaned and stored in distilled water at $4{ }^{\circ} \mathrm{C}$. The teeth were decoronated using a water-cooled diamond disk (\#7020; KG Sorensen, Barueri, SP, Brazil). Teeth were randomly divided into 4 groups for both substrates $(n=10)$ : NEndNIr, non-endodontically treated and non-irradiated; EndNIr, endodontically treated and non-irradiated; NEndIr, non- treated and irradiated; Endlr, treated and irradiated. For non-endodontically treated teeth, pulp was removed followed by saline irrigation. For the treated teeth, root canals were instrumented using 40 and $80 \mathrm{~K}$-files for human and bovine teeth, respectively (K-files, Dentsply Maillefer, Ballaigues, Switzerland), at a working length of $1.0 \mathrm{~mm}$ from the apex. A step-back technique was used with stainless-steel K-files, GatesGlidden drills 2 to 4 (Dentsply Maillefer), and a 2.0\% chlorhexidine irrigation (Biopharma, Uberlândia, MG, Brazil). The roots were filled with gutta-percha and calciumhydroxide based cement (Sealer 26; Dentsply, Petrópolis, RJ, Brazil) by lateral condensation technique. Endodontic accesses were sealed with conventional glass ionomer cement (Vidrion R; SS White, Rio de Janeiro, RJ, Brazil).

The teeth from irradiated groups were immersed in distilled water, and the radiotherapy protocol was applied with 60 Gy of Co-60 gamma radiation, fractionated into 2 Gy daily doses, 5 days per week $(2,3)$. This protocol is similar to that used in patients under oncogenic treatment for head and neck tumors and performed in a specialized cancer center with a Co-60 teletherapy unit (Theratron Phoenix External Beam Therapy System; Best Theratronics
Ltd., Ottawa, ON, Canada). For the mechanical tests, roots were sectioned along their long axis using a diamond saw (Isomet 1000; Buehler, Lake Bluff, IL, USA) resulting into two halves, one for each experimental test (Fig. 1). The tests were performed $24 \mathrm{~h}$ after the specimens were finished.

\section{Three-Point Bending Test}

Flexural strength was obtained using half the root dentin obtained previously for the mini-flexural strength test set up (14). Plano-parallel dentin bars of $2.0 \pm 0.1 \mathrm{~mm}$ thick $2.0 \pm 0.1 \mathrm{~mm}$ wide and $12.0 \pm 0.3 \mathrm{~mm}$ long were obtained for each tooth. The samples were tested in a mechanical testing machine (EMIC DL2000; São José dos Pinhais, PR, Brazil), with a rounded-edge tip at a crosshead speed of $0.5 \mathrm{~mm} / \mathrm{min}$ until fracture of the specimens. The flexural strength was calculated by the formula: $\delta f=3 P L \mid 2 b h^{2}$, where $P$ is the load $(N)$ at the highest point of load-deflection curve, $L$ is the span length $(10.0 \mathrm{~mm}), b$ is the width and $h$ is the thickness of the specimen. The values $b$ and $h$ were measured with a digital caliper (S500-171-20B; Mytutoyo, Suzano, SP, Brazil). The data were analyzed by three-way ANOVA $(2 \times 2 \times 2)$ followed by Tukey HSD test $(\alpha=0.05)$.

\section{Knoop Microhardness Test}

Knoop hardness was calculated for the cervical, medium and apical dentin thirds (Fig. 1). The specimens were embedded in polystyrene resin (AM 190 Resin; Aerojet, São Paulo, SP, Brazil). The surfaces were ground with silicon carbide papers (\#600, 800, 1200, 1500; Norton, Campinas,
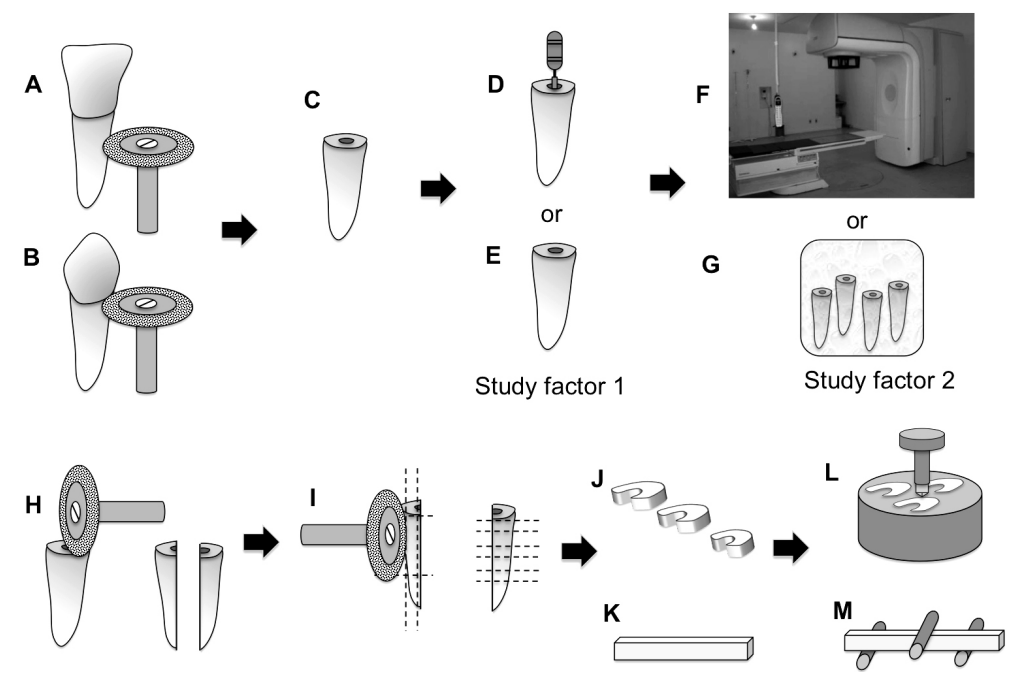

Figure 1. Diagram indicating the locations from which the dentin specimens were taken for hardness and flexural strength tests. A. Bovine teeth; B. Human teeth, sectioned transversally; C. root tooth $15 \mathrm{~mm}$ long; D. Endodontic treatment realized in End group; E. root of NEnd group; F. Radiation performed in Ir group; G. roots of NIr group; $\mathrm{H}$. root sample cut with diamond saw providing two halves from the same tooth; $\mathrm{H}$. preparation of the samples for both mechanical tests; J. root slices of apical, medium and cervical dentin; K. dentin bar; L. Knoop hardness test; M. three-point bending test. 
SP, Brazil) and polished with diamond pastes $(6,3,1,0.25$ $\mu \mathrm{m}$; Arotec, São Paulo, SP, Brazil). The Knoop indentation values were determined with a microhardness tester (FM700; FutureTech Corp., Kawasaki, Japan) by applying a load of $50 \mathrm{~g}$ for $15 \mathrm{~s}(15)$. Three indentations were made in each specimen and the mean microhardness value (KHN) was calculated for each root third. Data and the mean values of the three thirds were submitted to three-way ANOVA $(2 \times 2 \times 2)$ followed by Tukey HSD test $(\alpha=0.05)$.

\section{Results}

The mean and standard deviation values of flexure strength are in Table 1. Three-way ANOVA indicated no significant difference for the flexural strength values among groups for the isolated factors, substrate $(p=0.491)$, endodontic treatment $(p=0.272)$, and radiotherapy $(p=0.152)$, neither for their interactions, substrate/ endodontic treatment $(p=0.233)$, substrate/radiotherapy $(p=0.360)$, endodontic treatment $/$ radiotherapy $(p=0.220)$, substrate/endodontic therapy/radiotherapy $(p=0.585)$.

The mean and standard deviation values of $\mathrm{KHN}$ values are in Table 2. The three-way ANOVA indicated significant influence of the dentin type $(p=0.000)$, the radiotherapy $\vec{s}$ protocol $(p=0.000)$ and endodontic treatment $(p=0.002)$. No significant influence was observed for the interactions dentin type/endodontic treatment $(\mathrm{p}=0.638)$, radiotherapy/ endodontic treatment $(p=0.238)$, dentin type/radiotherapy $(p=0.244)$, dentin type/endodontic treatment/radiotherapy $(p=0.358)$. Tukey's test demonstrated that human dentin had higher KHN than the bovine, irrespective of endodontic treatment and radiotherapy application. The radiotherapy reduced significantly the KHN of root dentin irrespective of endodontic treatment and dentin type. The endodontic treatment also reduced significantly the KHN values of root dentin, irrespective of dentin type and radiotherapy.

\section{Discussion}

The first null hypothesis was rejected. Although, the Co-60 gamma radiation or the endodontic treatment influenced the flexural strength of human and bovine root dentin, radiotherapy and endodontic treatment reduced significantly the KHN values of human and bovine dentin. The second null hypothesis was also rejected, since the human dentin had higher KHN values than bovine dentin whether submitted or not to endodontic treatment or radiotherapy.

Dentin is the composite mineralized tissue with mechanical properties essential to protect enamel, maintaining the stress/strain tooth behavior (16). The mineral content of dentin is an important and determining factor of hardness values, while the organic content is more related to the fracture strength of the tissue (17). Radiation has a direct destructive effect on dental hard tissues, especially at the dentin-enamel junction $(1,2,15)$.

Table 1. Mean flexural strength values (MPa) and standard deviation for interaction between radiotherapy protocol and endodontic therapy for human and bovine root dentin

\begin{tabular}{|c|c|c|c|c|c|c|}
\hline \multirow[b]{2}{*}{ Radiotherapy } & \multicolumn{3}{|c|}{ Human dentin } & \multicolumn{3}{|c|}{ Bovine dentin } \\
\hline & $\begin{array}{l}\text { Endodontic } \\
\text { treatement }\end{array}$ & $\begin{array}{l}\text { No endodontic } \\
\text { Treatement }\end{array}$ & Pooled Average & $\begin{array}{l}\text { Endodontic } \\
\text { treatement }\end{array}$ & $\begin{array}{l}\text { No endodontic } \\
\text { Treatement }\end{array}$ & Pooled Average \\
\hline Irradiated & $1357.9 \pm 491.1$ & $1574.2 \pm 1105.9$ & $1466.1 \pm 765.0^{\mathrm{A}}$ & $1322.1 \pm 509.5$ & $1471.0 \pm 473.0$ & $1396.5 \pm 367.1^{\mathrm{B}}$ \\
\hline Non-irradiated & $1582.5 \pm 534.3$ & $1982.6 \pm 425.3$ & $1744.2 \pm 389.8^{\mathrm{A}}$ & $1454.3 \pm 419.7$ & $1679.7 \pm 511.8$ & $1567.7 \pm 401.9^{\mathrm{A}}$ \\
\hline Pooled Average & $1470.2 \pm 398.5^{\mathrm{a}}$ & $1740.1 \pm 865.2^{\mathrm{a}}$ & & $1388.2 \pm 378.6^{\mathrm{a}}$ & $1575.4 \pm 11.4^{\mathrm{a}}$ & \\
\hline
\end{tabular}

Different upper case letters indicate significant differences for radiotherapy factor; different lower case letters indicate significant difference for endodontic therapy factor. Comparison performed by Tukey HSD test $(\mathrm{p}<0.05)$.

Table 2. Mean microhardness values (KHN) and standard deviation for interaction between radiotherapy protocol and endodontic therapy for human and bovine root dentin

\begin{tabular}{|c|c|c|c|c|c|c|}
\hline \multirow[b]{2}{*}{ Radiotherapy } & \multicolumn{3}{|c|}{ Human dentin } & \multicolumn{3}{|c|}{ Bovine dentin } \\
\hline & $\begin{array}{l}\text { No Endodontic } \\
\text { Treatement }\end{array}$ & $\begin{array}{l}\text { Endodontic } \\
\text { Treatement }\end{array}$ & Pooled Average & $\begin{array}{c}\text { No Endodontic } \\
\text { Treatement }\end{array}$ & $\begin{array}{l}\text { Endodontic } \\
\text { Treatement }\end{array}$ & Pooled Average \\
\hline Non-irradiated & $59.9 \pm 11.2$ & $50.4 \pm 7.9$ & $55.2 \pm 9.8^{\mathrm{A}}$ & $48.7 \pm 13.6$ & $40.7 \pm 6.9$ & $44.7 \pm 11.9^{\mathrm{A}^{*}}$ \\
\hline Irradiated & $50.2 \pm 9.9$ & $41.1 \pm 9.3$ & $45.7 \pm 9.0^{\mathrm{B}}$ & $38.6 \pm 10.0$ & $31.7 \pm 11.1$ & $35.2 \pm 11.1^{\mathrm{B}^{*}}$ \\
\hline Pooled Average & $55.1 \pm 9.2^{\mathrm{a}}$ & $45.8 \pm 6.5^{b}$ & & $43.7 \pm 11.4^{\mathrm{a}^{*}}$ & $36.2 \pm 9.9^{b^{*}}$ & \\
\hline
\end{tabular}

Different upper case letters indicate significant differences for radiotherapy factor; different lower case letters indicate significant difference for endodontic therapy factor; * indicates the significant differences for substrate factor. Comparison performed by Tukey HSD test ( $<<0.05$ ). 
The ionizing radiation produces tissue damage by two basic mechanisms, the direct and the indirect processes (19). The majority of the biologic injuries is resulting from the indirect effects of the irradiation on the tissues. This mechanism involves the reaction of the target-tissue with the free radicals produced by the irradiation action over the water, which includes $\mathrm{OH}$ radicals and hydrated electron radicals (19). It is in accordance with the results of this study, which supports that the Co-60 gamma radiation produced deleterious effects on the microhardness of the human and bovine dentin, probably by the deterioration, to some degree, of the organic and mineral contents.

A decrease in the cohesive strength of the human dentin was verified using a similar irradiation protocol applied on this study (4). In a scanning electron microscopy evaluation, the authors found a high percentage of microfractures in dentin, which may explain the decrease of microhardness values in this investigation. Radiotherapy had no influence on the flexural strength of the human and bovine dentin. However, this finding should be considered with some reservation. The authors assumed that preparation of specimens for this mechanical test is very technique-dependent, which seems to make it less sensitive for identification of microstructural changes in dentin, differing from the microhardness test, which is more adequate to detect such small alterations.

Characteristic structural alterations that commonly affect irradiated teeth are called poor ramifications of the odontoblastic extensions near the dentinoenamel junction and obliteration of the dentin tubules before the limits of the hard tissues (20). Tubule obliteration followed by the degeneration of the odontoblastic extensions is a direct result from the cell damage induced by radiation, reducing the metabolism, mainly on the terminal area of the odontoblastic cells (21). Beside these microstructural changes, other modifications in the mechanical properties of the dentin may occur, like the reduction of microhardness observed in the teeth of both species submitted to radiotherapy. The reduction of the microhardness values would indeed be a direct factor contributing to radiation caries (13). Patients in active radiotherapy or those to be submitted to this treatment, require differential care due their increased susceptibility to oral disturbances. Full comprehension of patient's oral condition before and after the radiotherapy sessions may establish parameters for preventive actions for the control of the side effects inherent to this therapeutic approach (22). The effect of chlorhexidine irrigation should be considered to protect the effect of the radiation protocol. A recent study that tested different rinse solutions demonstrated that intracanal chlorhexidine rinse used on root dentine enhanced the fracture resistance of roots filled with AH Plus (23).
Obtaining sound human teeth for laboratory researches is becoming ever more difficult. Besides the ethical restrictions, limitations in collection and standardizing, and the reduced frequency of dental extractions, make the use of human teeth even more limited (24). Thus, teeth from other mammals are used in substitution to the human, and the bovine are frequently the common choice due to its similarity and easy achievement $(25,26)$. In this way, evaluation of the mechanical properties of this class of teeth is important for substituting human teeth in researches without discrepancies in the results. Despite the number of dentin tubules and their diameter being similar on the coronal portion for human and bovine root dentin, the mean diameter of the tubules in bovine dentin is superior to the human (27). The variation of the quantity of peritubular dentin, which represents the most mineralized portion of the dentin substrate and also the variation of the quantity of intertubular dentin, associated with the hydroxyapatite crystals, may explain the differences found between the KHN values of both substrates. These findings do not eliminate the possibility of the bovine teeth as a substitute for human teeth, but could be interpreted as a limitation of the direct correlation of in vitro test that use bovine teeth for direct clinical correlation.

Another significant result demonstrated in this study was the change of the mechanical properties of the human and bovine dentins observed when the endodontic treatment and radiotherapy were associated. As previously shown, with radiation, the organic and mineral portions of dentin can be altered, consequently modifying its mechanical properties $(1-3,13,28)$. It may be suggested that the association between these two factors could promote increased deleterious effects in the dentin of root filled teeth, since endodontic therapy can also cause changes in the mechanical properties of teeth as well (7). Therefore, careful maintenance of these teeth is advised for patients with head and neck tumors that need radiotherapy.

This study was conducted in laboratorial conditions and it presents intrinsic limitations such as the nonsimulation of the support and protection tissues during the radiotherapy protocol application. Additionally, this study did not isolate the effect of the irrigation during the endodontic therapy. Future laboratory studies contemplating alterations in the mechanical properties of endodontically treated teeth in patients under radiotherapy for treatment of head and neck tumors are advisable, suggesting new approaches and allowing better prognoses for teeth, enhancing consequently the quality of life for these patients. Within the limitations of this laboratory study, the conclusions were: the flexural strength of both evaluated substrates was not influenced by the Co-60 gamma radiotherapy protocol neither by the endodontic 
treatment; the radiotherapy and the endodontic treatment reduced significantly the microhardness of human and bovine dentin and the association between the radiotherapy and the endodontic treatment promoted a greater reduction in the microhardness of human and bovine dentin.

\section{Resumo}

Este estudo avaliou o efeito da irradiação gama e tratamento endodôntico na microdureza e resistência à flexão de dentina radicular humana e bovina. Quarenta dentes humanos unirradiculares e quarenta dentes incisivos bovinos foram coletados, limpos e armazenados em água destilada a $4{ }^{\circ} \mathrm{C}$. Os dentes humanos e bovinos foram divididos em 4 grupos $(n=10)$ gerados pela combinação de dois fatores de estudo: tratamento endodôntico em 2 niveis: com ou sem tratamento endodôntico; e radioterapia em dois niveis: com ou sem radioterapia utilizando 60 Gy de radiação gama de Co-60 fracionado em 2 Gy por dia, cinco dias por semana. Cada dente recebeu um corte longitudinal, resultando em duas metades por raiz, sendo uma metade utilizada para o ensaio de flexão de três pontos e a outra para o teste de dureza Knoop (KHN). Os dados foram analisados por ANOVA e teste de Tukey $(\alpha=0,05)$. Nenhuma diferença estatistica foi encontrada para todos os fatores de resistência à flexão. A dentina humana teve KHN significativamente maior do que a dentina bovina. 0 tratamento endodôntico e radioterapia resultaram em significativa menor $\mathrm{KHN}$, independentemente do tipo de dente. Os resultados indicaram que a radioterapia produziu efeitos deletérios sobre a microdureza da dentina humana e bovina e este efeito é exacerbado pela interação com a terapia endodôntica. 0 tratamento endodôntico causou efeito negativo adicional à radioterapia nas propriedades mecânicas da dentina. Este aspecto deve ser considerado no momento de se restaurar dentes tratados endodonticamente que receberam terapia endodôntica

\section{Acknowledgements}

The authors are indebted to FAPEMIG and CAPES for financial support and would like to acknowledge the Cancer Hospital of the Federal University of Uberlândia for providing the radiation equipment and technical support. This study was performed at CPBio, Biomechanics, Biomaterials and Cell Biology Research Center.

\section{References}

1. Springer IN, Niehoff P, Warnke PH, Bocek G, Kovacs G, Suhr M, et al.. Radiation caries - radiogenic destruction of dental collagen. Oral Oncol 2005; $41: 723-728$.

2. Reed R, Xu C, Liu Y, Gorski JP, Wang Y, Walker MP. Radiotherapy effect on nano-mechanical properties and chemical composition of enamel and dentine. Arch Oral Biol 2015;60:690-697.

3. Gonçalves LM, Palma-Dibb RG, Paula-Silva FW, Oliveira HF, NelsonFilho P, Silva LA, et al.. Radiation therapy alters microhardness and microstructure of enamel and dentin of permanent human teeth. J Dent 2014;42:986-992.

4. Soares CJ, Castro CG, Neiva NA, Soares PV, Santos-Filho PC, Naves LZ, et al.. Effect of gamma irradiation on ultimate tensile strength of enamel and dentin. J Dent Res 2009;89:159-164.

5. Soares CJ, Neiva NA, Soares PB, Dechichi P, Novais VR, Naves LZ, et al.. Effects of chlorhexidine and fluoride on irradiated enamel and dentin. J Dent Res 2011;90:659-664.

6. Pioch T, Golfels D, Staehle HJ. An experimental study of the stability of irradiated teeth in the region of the dentinoenamel junction. Endod Dent Traumatol 1992;8:241-244.

7. Zero DT, Zandona AF, Vail MM, Spolnik KJ. Dental caries and pulpal disease. Dent Clin North Am 2011;55:29-46.

8. Soares CJ, Santana FR, Silva NR, Preira JC, Pereira CA. Influence of the endodontic treatment on mechanical properties of root dentin. J Endod
2007:33:603-606.

9. Blaser PK, Lund MR, Cochran MA, Potter RH. Effect of designs of Class 2 preparations on resistance of teeth to fracture. Oper Dent 1983;8:6-10.

10. Lilly JP, Cox D, Arcuri M, Krell KV. An evaluation of root canal treatment in patients who have received irradiation to the mandible and maxilla. Oral Surg Oral Med Oral Pathol Oral Radiol Endod 1998;86:224-226.

11. de Siqueira Mellara T, Palma-Dibb RG, de Oliveira HF, Garcia Paula-Silva FW, Nelson-Filho P, da Silva RA, et al.. The effect of radiation therapy on the mechanical and morphological properties of the enamel and dentin of deciduous teeth--an in vitro study. Radiat Oncol. 2014;22:9:30.

13. Kielbassa AM, Beetz I, Schendera A, Hellwig E. Irradiation effects on microhardness of fluoridated and non-fluoridated bovine dentin. Eur J Oral Sci 1997;105:444-447.

12. Teruel J de D, Alcolea A, Hernández A, Ruiz AJ. Comparison of chemical composition of enamel and dentine in human, bovine, porcine and ovine teeth. Arch Oral Biol. 2015 May;60:768-775.

14. Yap AU, Teoh SH. Comparison of flexural properties of composite restoratives using the ISO and mini-flexural tests. J Oral Rehabil 2003;30:171-177.

15. Habelitz S, Marshall SJ, Marshall GW, Jr., Balooch M. Mechanical properties of human dental enamel on the nanometre scale. Arch Oral Biol 2001;46:173-183.

16. Giannini M, Soares $\mathrm{CJ}$, de Carvalho RM. Ultimate tensile strength of tooth structures. Dent Mater 2004;20:322-329.

17. Angker L, Nijhof N, Swain MV, Kilpatrick NM. Influence of hydration and mechanical characterization of carious primary dentine using an ultra-micro indentation system (UMIS). Eur J Oral Sci 2004;112:231236.

18. Lieshout HF, Bots CP. The effect of radiotherapy on dental hard tissue-a systematic review. Clin oral Investig 2014;18:17-24.

19. Sarkaria JN, Bristow RG. Overview of cancer molecular radiobiology. Cancer Treat Res 2008;139:117-133.

20. Grotz KA, Duschner H, Kutzner J, Thelen M, Wagner W. [New evidence for the etiology of so-called radiation caries. Proof for directed radiogenic damage od the enamel-dentin junction]. Strahlenther Onkol 1997:173:668-676

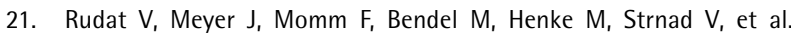
Protective effect of amifostine on dental health after radiotherapy of the head and neck. Int J Radiat Oncol Biol Phys 2000;48:1339-1343.

22. Allison PJ, Locker D, Feine JS. The relationship between dental status and health-related quality of life in upper aerodigestive tract cancer patients. Oral Oncol 1999;35:138-143.

23. Turk T, Kaval ME, Sarikanat M, Hülsmann M. Effect of final irrigation procedures on fracture resistance of root filled teeth: an ex vivo study. Int Endod J 2016 [Epub ahead of print. doi: 10.1111/iej.12680.]

24. Fonseca RB, Haiter-Neto F, Fernandes-Neto AJ, Barbosa GA, Soares CJ. Radiodensity of enamel and dentin of human, bovine and swine teeth. Arch Oral Biol 2004;49:919-922.

25. Schilke R, Lisson JA, Bauss O, Geurtsen W. Comparison of the number and diameter of dentinal tubules in human and bovine dentine by scanning electron microscopic investigation. Arch Oral Biol 2000;45:355-361.

26. Fonseca RB, Haiter-Neto F, Carlo HL, Soares CJ, Sinhoreti MA, PuppinRontani RM, et al.. Radiodensity and hardness of enamel and dentin of human and bovine teeth, varying bovine teeth age. Arch Oral Biol 2008;53:1023-1029.

27. Camargo $\mathrm{CH}$, Siviero $\mathrm{M}$, Camargo $\mathrm{SE}$, Oliveira $\mathrm{SH}$, Carvalho $\mathrm{CA}$, Valera MC. Topographical, diametral, and quantitative analysis of dentin tubules in the root canals of human and bovine teeth. J Endod 2007;33:422-426.

28. Liang X, Zhang JY, Cheng IK, Li JY. Effect of high energy X-ray irradiation on the nano-mechanical properties of human enamel and dentine. Braz Oral Res 2016;30:1-9. 